\title{
EFFECT OF EGG AGE AND FERTILITY ON SOME BIOLOGICAL ASPECTS OF THREE TRICHOGRAMMA SPECIES
}

\author{
MANAL A. A. EL SHARKAWY
}

Plant Protection Research Institute, ARC, Dokki, Giza, Egypt

(Manuscript received 18 January 2011)

\begin{abstract}
Two laboratory experiments were carried out to determine the effect of egg age and its fertility on fecundity, progeny survival and sex-ratio of three trichogrammatids i.e., Trichogramma evanescens, Trichogrammatoidea bactrae and Trichogramma brassicae. In the first experiment, three different ages (one, two and three days old) of fertile eggs from three lepidopterous hosts (Pectinophora gossypiella Saund., Agrotis ipsilon Hufn. and Sitotroga cerealella Olivier) were introduced to Trichogramma females. In the second experiment, infertile eggs of $P$. gossypiella and $A$. ipsilon were introduced to Trichogramma females to test the acceptability of these eggs to be parasitized by those females. The number of parasitized eggs/ female was higher on $0-1$ day old eggs and decreased significantly as the host eggs became older. Higher percentages of progeny were emerged from all the tested ages of $P$. gossypiella and $S$. cerealella eggs. On the other hand, the emerged progeny of the three Trichogramma species was decreased significantly by the progress of embryo development in $A$. ipsilon eggs. Furthermore, infertile $P$. gossypiella and $A$. ipsilon eggs were not accepted by the three Trichogramma species.
\end{abstract}

\section{INTRODUCTION}

It is known that host age is one of the most important factors determining host acceptance by insect parasitoids (Vinson, 1985). In most species of Trichogramma, the number of parasitized hosts decreases with increasing development of the host's embryo. Parasitoids usually show a significant preference for young host eggs, and some Trichogramma females refuse to parasitize old eggs ( $\mathrm{Li}$ and Henderson, 1993, Shoeb 2000). In this respect, Abd El-Hafez (1994) found that females of $T$. evanescens and T. bactrae preferred to oviposit into young pink and spiny bollworm eggs than old ones. The white pink bollworm eggs were significantly preferred to orange and head capsule eggs. The age of host eggs involved in Trichogramma production in at least two ways. Firstly, the oviposition preference of the parasitoid females and secondly, as an indicator of the resource quality available for the developing parasitoid larvae thus affecting the physiology of host parasitoid interaction (Vinson and Iwantsch, 1980). PAK (2009) stated that the relationship between types may also vary between different Trichogramma species on the same host species. This indicates the importance of studying host-age selection for the 
evaluation of candidate Trichogramma strains for inundative biological control programs. The present studies have been conducted for two aims, the first aim was to investigate the effect of host embryo development on the efficiency of Trichogramma. The second aim is to study the acceptability and suitability of infertile host eggs for the parasitoid and the compatibility of using infertile host eggs for mass production of Trichogramma in an integrated program to avoid rapid development of the host embryo.

\section{MATERIALS AND METHODS}

The experiments were carried out at $27^{\circ} \mathrm{C} \pm 1$ and $80 \pm 5 \%$ R. H. in Bollworms Department, Plant protection Research Institute, ARC, Dokki, Giza, Egypt. Host rearing:

Pink bollworm Pectinophora gossypiella (Saunders) was reared on modified artificial diet as described by Abd El-Hafez, et al. (1982). Where angoumois grain moth Sitotroga cerealella (Olivier) was reared on wheat grains according to ElSharkawy (2002). As for black cutworm, Agrotis ipsilon (Hufn.) it was reared on castor-bean leaves using the same technique as described by Fahmy et al., (1973)

\section{Parasitoid rearing}

The three parasitoids were reared on eggs of the three aforementioned hosts in the laboratory according to El-Sharkawy (2002).

\section{Experimental techniques}

Pupae of the three hosts were separated individually in glass vials $(2 \times 7 \mathrm{~cm})$ and kept under rearing conditions until moth emergence. To obtain fertile eggs from the three hosts, five pairs of newly emerged male and female moths from each host were kept together into ovipotion cage. As for obtaining infertile eggs, five newly emerged females from $P$. gossypiella and $A$. ipsilon pupae were placed into ovipotion cage. Eggs were collected daily and incubated at the same conditions.

In the first experiment, fertile eggs of the three hosts were classified according to its age i.e., 0-one, one-two and two-three days old. For each host, twenty mated Trichogramma females from each parasitoid were placed individually in glass vials $(5 \times 12 \mathrm{~cm})$ containing sixty host eggs from each age. The vials were covered with pieces of cloth-wrapped cotton kept in position by rubber band and maintained at the same conditions. The number of parasitized host eggs was counted after five days, the percentage of emergence and sex ratio for emerged progeny were calculated after adult emergence. 
In the second experiment, infertile eggs (0-one-day old) of $P$. gossypiella and $A$. ipsilon were introduced to Trichogramma females to investigate their acceptability to those eggs. Twenty females were maintained individually in glass vials, each vial was containing sixty infertile host eggs (0-one day old). In comparison, another identical group of twenty females were maintained individually in glass vials containing sixty fertile eggs of 0 -one-day old. The number of parasitized host eggs was counted after five days in order to calculate the percentage of parasitism. The percentage of emergence and sex ratio of emerged progeny were calculated.

Analysis of variance were done on all data (ANOVA) and when statistical differences existed within a data set, Duncan's multiple range test was used to separate the means (Snedecor \& Cochran 1980).

\section{RESULTS AND DISCUSSION}

\section{Effect of fertile egg age on some biological aspects of Trichogramma Effect on number of parasitized eggs}

Data in Table (1) show that 0-one day old eggs of the three hosts was the most accepted age by females of the three Trichogramma species. Parasitoid females parasitized the greatest number of eggs when introducing 0 -one day old eggs, this number decreased gradually as the egg age advanced. Regardless the parasitoid specie, it averaged 38.17, 34.42 and 27.18 eggs/ female for 0-one, onetwo and two-three days old eggs of $P$. gossypiella, respectively. As for the other two hosts, it averaged $32.18,24.48$ and 23.13 eggs/ female for $S$. cerealella and 25.38, 9.18 and 1.6 eggs/ female for $A$. ipsilon, respectively. Regarding the parasitoid species, the same level of acceptability was achieved by $T$. evanescens female. The number of parasitized eggs of the three age classes averaged 46, $32.15 \& 30.5$ eggs/ female, 36, $22.95 \& 20.95$ eggs/ female and 25.9, $11.1 \& 1.95$ eggs/ female in case of $P$. gossypiella, S. cerealella and A. ipsilon, respectively. On the other hand, the number of parasitized eggs by $T$. bactrae female show insignificant differences between the first two age classes of $P$. gossypiella (30.4 \&33.2 eggs/ female) and $S$. cerealella eggs (29.65 \& 27.5 eggs/ female). Whereas significant differences were found between the three age classes of $A$. ipsilon eggs (25.65, 6.71 and 1.9 eggs/ female, respectively). As for $T$. brassicae there were insignificant differences between the first two age classes of $P$. gossypiella (38.1 and 37.9 eggs/ female) and between the last two age classes of $S$. cerealella eggs ( 23 and 23.6 eggs/ female).

Regardless of host species and ages, there were insignificant differences between $T$. evanescens and $T$. brassicae, as the mean number of parasitized eggs 
was 25.28 and 24.26 eggs/ female. While it averaged 22.38 eggs/ female in case of T. bactrae (L.S.D. $=1.96)$. Regardless of the parasitoid species or the host ages, $P$. gossypiella eggs was the most acceptable host by the three parasitoid species as the whole mean of parasitized eggs was 33.26 eggs/ female, where it was 26.6 and 12 . 06 eggs/ female in case of $S$. cerealella and $A$. ipsilon, respectively. The low acceptance of $A$. ipsilon old eggs (more than one day old) may suggest that the embryo in these eggs developed rapidly comparing with the other two hosts. Generally, it could be concluded that 0-one day old eggs is the most acceptable age for Trichogramma spp. P. gossypiella eggs is the most acceptable host for the three parasitoid species and $T$. evanescens \& $T$. brassicae are more effective in parasitizing eggs of the three hosts than T. bactrae.

Data obtained in this study are agree with the finding of Hutchison et al. (1990) for T. bactrae in pink bollworm eggs and Abd El- Hafez, Alia (1994) for T. bactrae and $T$. evanescens in pink and spiny bollworm eggs. Also, similar results were obtained by Farid et al. (2001) who found that T. chilonis preferred one-day-old eggs as compared to 2 - 3 days old eggs. While, Muhammad Zahid et al. (2007) did not reveal an overall treatment effect of host egg age on parasitism by $T$. chilonis and found that $T$. chilonis does not discriminate between host ages of less than one day. PAK (2009) mentioned that the high acceptance rates of very young eggs may suggest that younger hosts, lacking a more developed embryo, are relatively easy to overcome. Another possible mechanism is host feeding: possibly, young S. cerealella eggs are a better source of adult nutrition than old eggs.

\section{Effect on percentage of emerged progeny}

The percentage of emerged progeny refers to the suitability of the used host for the parasitoid development. Data in Table (2) show high percentages of progeny emerging from the three tested ages (0-1 day, 1-2 days and 2-3 days old) of $P$. gossypiella eggs (89.4, 90.1 and $85.18 \%$, respectively) and $S$. cerealella eggs (90.25, 89.25 and $86.65 \%$, respectively). Statistical analysis show insignificant differences between these data. On the contrary, highly significant differences were found between the three ages of $A$. ipsilon eggs. The rapid growth of $A$. ipsilon embryo reflected on the development of immature stages of Trichogramma in these eggs. The percentage of emerged progeny decreased drastically from 95.8 to 82.4 and $39.4 \%$ by progress of embryo development from $0-1$ day to $1-2$ and 2-3 days old, respectively. The present results are in agreement with (King, 1989), who found that the number of emerging parasitoids per host decreased with host age, and he suggested that ovipositing females adjusted clutch size to decreasing host quality. Also Miura kazuki 1998 stated that the emergence rate of T. chilonis was high on the 
1-day-old eggs, but did not differ among other host ages, except the 3-day-old host. T. chilonis progeny failed to complete development on the 3-day-old Plutella xylostella eggs. Several studies show that female parasitoids will lay more eggs and oviposit more readily in younger hosts, and that survival of progeny decreases with host age (Pak and Oatman, 1982).

\section{Effect on sex-ratio of the emerged progeny}

Data in Table (3) show that, the percentage of females in emerged progeny decreased significantly with the increase of host age. Regardless of parasitoid species, total mean of percentage females in emerged progeny decreased gradually by progress of embryo development in eggs. These percentages were calculated as $67.4,58.26$ and $47.80 \%$ in case of $0-1,1-2$ and 2-3 days old of $P$. gossypiella eggs, $64.46,55.9$ and $52.7 \%$ in case of $S$. cerealella and $61.7,55.8$ and $37.5 \%$ in case of A. ipsilon eggs, respectively. Regardless of the host species and its age, there were insignificant differences between the three parasitoid species, as the percentages of sex ratio were $55.4,55.2$ and $56.6 \%$ for $T$. evanescence, $T$. bactrae and $T$. braccicae, respectively. Clutch size and offspring sex ratio vary with the female's assessment of host size, age, nutritional suitability, and previous parasitization (Schmidt, 1994). In solitary parasitoids, adult size is correlated with host size (King 1989 and Abd ElHafez, 2001). This relation can also apply to other host quality factors such as host age and species (Vinson \& Iwantsch, 1980). Charnov's host quality model (Charnov et al., 1981) predicts that mothers should produce a greater proportion of sons under conditions that will result in smaller offspring. They added that when a female parasitoid of a solitary or facultative gregarious species allocates resources among different hosts in which only one parasitoid can develop, it is expected that more males are allocated in the least preferred hosts.

\section{Influence of infertile eggs on some biological aspects of Trichogramma Effect on percentage of parasitized host eggs}

Data in Table (4) show highly significant difference between percentage of parasitism on fertile and infertile eggs of $P$. gossypiella and $A$. ipsilon. Regardless of parasitoid species, the mean percentage of parasitism on eggs of the two hosts decreased drastically from 75.9 and $77.51 \%$ when the females were introduced fertile eggs to $6.12 \%$ and $8.33 \%$ when infertile eggs were introduced to those females. On the other hand, insignificant differences were found between percentages of parasitism by the three parasitoids females when parasitized either fertile or infertile eggs of the two hosts. The lower acceptance of infertile eggs by Trichogramma females was explained by Olson (1998) who mentioned that females are able to detect the host embryo at the egg surface using visual, olfactory, and/or 
tactile cues. Trichogramma females may be able to see the embryo through the egg chorion, they may detect chemicals produced by the host embryo with chemoreceptor sensillae on their antennae. He added that hosts with no embryo, females may show no preference for accepting a host within different parts of the host egg. The present results are disagree with those of Makee (2006) who found that the tendency of $T$. cacoeciae females to attack infertile eggs was similar to that of fertile eggs, whereas T. principium showed a greater preference for infertile eggs than fertile eggs, and fertility status of the host did not affect the number of eggs that were parasitized.

\section{Effect on percentage of emerged progeny}

As mentioned before, the percentage of emergence considered a conductor for the suitability of host eggs. Data in Table (5) indicate that infertile host eggs were unsuitable for development of parasitoid offsprings, as the mean percentage of emergence decreased from $90.62 \%$ in case of fertile $P$. gossypiella eggs to $66.46 \%$ when development occurred in infertile eggs of the same host. Also it decreased from $94.73 \%$ to $56.05 \%$ for fertile and infertile $A$. ipsilon eggs, respectively. Infertile $P$. gossypiella eggs were more suitable for growing $T$. evanescence and $T$. braccicae, than those of $A$. ipsilon, as the percentages of emergence were $75.42 \% \& 61.97 \%$ and $48.77 \% \& 51.96 \%$, respectively. While there was insignificant difference between infertile $P$. gossypiella (62.01\%) and $A$. ipsilon (67.43\%) eggs in case of $T$. bactrae. Olson 1998 stated that, some of the fresh host eggs presented to females may have not been fertilized which may have also affected parasitoid survival. The present results are in agreement with that of Makee (2006) who mentioned that fewer $F_{1}$ progeny emerged from infertile eggs when parasitized than from fertile eggs. The present results are close to those of AN Dahlan Gordon Gordh (1997 who stated that $20 \%$ of parasitized infertile eggs ( $<12 \mathrm{~h}$ old) produced adult wasps but their number was significantly lower $(P<0.05)$ than those from fertile eggs.

\section{Effect on sex ratio of the emerged progeny}

Data in Table (6) indicated that there were highly significant differences between percentages of Trichogramma females in progeny which emerged from fertile and infertile host eggs. The percentage of females emerged from fertile $P$. gossypiella and $A$. ipsilon eggs were 66.4 and $61.72 \%$, these percentages decreased significantly to 44.54 and $47.06 \%$ in progeny from infertile eggs of the two hosts, respectively. Moreover, there were significant differences between percentages of Trichogramma females in progeny from infertile $P$. gossypiella and $A$. ipsilon eggs when parasitized by $T$. evanescence $(28.02 \& 40.55 \%)$ and $T$. brassicae (55.65\& $38.90 \%$ ). Whereas, there were insignificant differences between the two hosts 
(51.08\& 59.29\%) when parasitized by T. bactrae. Regardless of the host species and egg fertility, there were insignificant differences in the percentage of emerged females between $T$. bactrae $(59.82 \%)$ and $T$. brassicae $(57.49 \%)$, where this percentage decreased significantly to $48.26 \%$ in case of $T$. evanescence. Generally, there were insignificant differences in percentage of females in progeny of the three parasitoids when emerged from fertile eggs of the two hosts, whereas, the opposite was true when emerged from infertile eggs.

It could be concluded that infertile eggs are unsuitable for rearing the three Trichogramma species. While few numbers of infertile eggs was accepted by females and low percentage of progeny emerged from these eggs with lower percentages of females. 
Table 4. Percentage (Mean \pm SD) of parasitism on fertile and infertile eggs by three trichogrammatids.

\begin{tabular}{|c|c|c|c|c|c|c|}
\hline \multirow{2}{*}{$\begin{array}{l}\text { Host } \\
\text { Parasite }\end{array}$} & \multicolumn{2}{|c|}{ P. gossypiella } & \multicolumn{2}{|c|}{ A. ipsilon } & \multirow{2}{*}{$\begin{array}{c}\text { Mean } \pm \\
\text { SD }\end{array}$} & \multirow[t]{2}{*}{ LSD } \\
\hline & Fertile & infertile & Fertile & infertile & & \\
\hline T. evanescens & $\begin{array}{c}74.2^{\mathrm{abA}} \pm \\
5.42\end{array}$ & $\begin{array}{c}5.51^{\mathrm{aB}} \pm \\
5.08\end{array}$ & $\begin{array}{c}79.59^{\mathrm{aA}} \pm \\
5.08\end{array}$ & $\begin{array}{c}6.52^{\mathrm{aB}} \pm \\
15.39\end{array}$ & $\begin{array}{c}41.46^{\mathrm{a}} \pm \\
36.75\end{array}$ & 7.14 \\
\hline T. bacrae & $\begin{array}{c}70.5^{\mathrm{bA}} \pm \\
6.73\end{array}$ & $\begin{array}{c}7.58^{\mathrm{aB} \pm} \\
11.77\end{array}$ & $\begin{array}{c}74.22^{\mathrm{aA}} \pm \\
7.24\end{array}$ & $\begin{array}{c}8.50^{\mathrm{aB} \pm} \\
8.11\end{array}$ & $\begin{array}{c}40.20^{\mathrm{a}} \pm \\
33.97\end{array}$ & 12.62 \\
\hline T. brassicae & $\begin{array}{c}82.98^{\mathrm{aA}} \pm \\
7.41\end{array}$ & $\begin{array}{c}5.27^{\mathrm{aB}} \pm \\
2.07\end{array}$ & $\begin{array}{c}78.72^{\mathrm{aA}} \pm \\
9.02\end{array}$ & $\begin{array}{c}11.48^{\mathrm{aB}} \pm \\
11.16\end{array}$ & $\begin{array}{c}44.61^{\mathrm{a}} \pm \\
38.02\end{array}$ & 10.92 \\
\hline $\begin{array}{l}\text { Mean } \\
\pm \text { SD }\end{array}$ & $\begin{array}{c}75.90^{\mathrm{A}} \pm \\
8.14\end{array}$ & $\begin{array}{c}6.12^{\mathrm{B}} \pm \\
7.02\end{array}$ & $\begin{array}{c}77.51^{\mathrm{A}} \pm \\
7.25\end{array}$ & $\begin{array}{c}8.33^{\mathrm{B}} \pm \\
8.19\end{array}$ & $\begin{array}{c}42.09 \pm \\
35.72\end{array}$ & 5.53 \\
\hline LSD & 9.059 & ns & ns & ns & $\mathrm{ns}$ & \\
\hline
\end{tabular}

Means followed by the same capital litter at the same row or by the same small litter at the same column are not significantly different. ANOVA yielded insignificant different between the three parasitoid species $(\mathrm{LSD}=4.79, \quad \mathrm{~F}=1.820)$.

Table 5. Percentage (Mean \pm SD) of emerged progeny of three trichogrammatids from fertile and infertile eggs.

\begin{tabular}{|c|c|c|c|c|c|c|}
\hline \multirow{2}{*}{$\begin{array}{l}\text { Host } \\
\text { Parasitoids }\end{array}$} & \multicolumn{2}{|c|}{ P. gossypiella } & \multicolumn{2}{|c|}{ A. ipsilon } & \multirow{2}{*}{$\begin{array}{l}\text { Mean } \pm \\
\text { SD }\end{array}$} & \multirow[t]{2}{*}{ LSD } \\
\hline & Fertile & infertile & $\mathrm{e}^{\text {Fertil }}$ & infertile & & \\
\hline T.evanescens & $\begin{array}{c}92.58^{\mathrm{aA}} \pm \\
4.25\end{array}$ & $\begin{array}{c}75.42^{\mathrm{aB}} \pm \\
13.07\end{array}$ & $\begin{array}{c}96.1^{\mathrm{aA}} \pm \\
3.02\end{array}$ & $\begin{array}{c}48.77^{\mathrm{aC}} \pm \\
22.13\end{array}$ & $\begin{array}{l}78.2^{\mathrm{a}} \pm \\
22.76\end{array}$ & 11.89 \\
\hline T. bacrae & $\begin{array}{c}86.49^{\mathrm{bA}} \pm \\
6.26\end{array}$ & $\begin{array}{c}62.01^{\mathrm{bB}} \pm \\
12.96\end{array}$ & $\begin{array}{c}95.3^{\mathrm{abA}} \pm \\
2.75\end{array}$ & $\begin{array}{c}67.43^{\mathrm{aB}} \pm \\
17.21\end{array}$ & $\begin{array}{c}77.8^{\mathrm{a}} \pm \\
17.53\end{array}$ & 10.25 \\
\hline T. brassicae & $\begin{array}{c}92.78^{\mathrm{aA}} \pm \\
4.19\end{array}$ & $\begin{array}{c}61.97^{\mathrm{bB}} \pm \\
8.13\end{array}$ & $\begin{array}{c}92.78^{\mathrm{bA}} \pm \\
4.19\end{array}$ & $\begin{array}{c}51.96^{\mathrm{aC}} \pm \\
18.93\end{array}$ & $\begin{array}{l}74.87^{\mathrm{a}} \\
\pm 21.16\end{array}$ & 9.72 \\
\hline Mean \pm SD & $\begin{array}{c}90.62^{A} \pm \\
5.66\end{array}$ & $\begin{array}{c}66.46^{\mathrm{B}} \pm \\
13.93\end{array}$ & $\begin{array}{c}94.73^{A} \pm \\
3.56\end{array}$ & $\begin{array}{c}56.05^{C} \pm \\
20.59\end{array}$ & $\begin{array}{c}76.96 \pm \\
20.48\end{array}$ & 6.02 \\
\hline LSD & 4.581 & 10.66 & ns & ns & ns & \\
\hline
\end{tabular}

Means followed by the same small litter at the same column or by the same capital litter at the same row are not significantly different. ANOVA yielded insignificant different between the three parasitoid species $(\mathrm{LSD}=1.393, \mathrm{~F}=1.475)$.

Table 6. Percentage (Mean $\pm S D$ ) of females in progeny of three trichogrammatids reared in fertile and infertile eggs

\begin{tabular}{|c|c|c|c|c|c|c|}
\hline \multirow{2}{*}{$\begin{array}{l}\text { Host } \\
\text { Parasite }\end{array}$} & \multicolumn{2}{|c|}{ P. gossypiella } & \multicolumn{2}{|c|}{ A. ipsilon } & \multirow[t]{2}{*}{ Mean \pm SD } & \multirow[t]{2}{*}{ LSD } \\
\hline & Fertile & infertile & Fertile & infertile & & \\
\hline T. evanescens & $\begin{array}{c}65.15^{\mathrm{aA}} \pm \\
7.72\end{array}$ & $\begin{array}{c}28.02^{\mathrm{bC}} \pm \\
9.53\end{array}$ & $\begin{array}{c}60.56^{\mathrm{aA}} \pm \\
2.6\end{array}$ & $\begin{array}{c}40.55^{\mathrm{bB}} \pm \\
7.84\end{array}$ & $\begin{array}{c}48.26^{b} \pm \\
16.91\end{array}$ & 6.80 \\
\hline T. bacrae & $\begin{array}{c}66.26^{\mathrm{aA}} \pm \\
9.25\end{array}$ & $\begin{array}{c}51.08^{\mathrm{aB}} \pm \\
8.82\end{array}$ & $\begin{array}{c}62.64^{\mathrm{aA}} \pm \\
4.37\end{array}$ & $\begin{array}{c}59.29^{\mathrm{aAB}} \pm \\
15.37\end{array}$ & $\begin{array}{c}59.82^{\mathrm{a}} \pm \\
11.35\end{array}$ & 9.27 \\
\hline T. brassicae & $\begin{array}{c}67.78^{\mathrm{aA}} \pm \\
9.80\end{array}$ & $\begin{array}{c}55.65^{\mathrm{aA}} \pm \\
16.25\end{array}$ & $\begin{array}{c}61.85^{\mathrm{aA}} \pm \\
3.54\end{array}$ & $\begin{array}{c}38.90^{\mathrm{bB}} \pm \\
19.35\end{array}$ & $\begin{array}{c}57.49^{\mathrm{a}} \pm \\
16.06\end{array}$ & 11.77 \\
\hline Mean \pm SD & $\begin{array}{c}66.40^{A} \pm \\
8.72\end{array}$ & $\begin{array}{c}44.54^{\mathrm{B}} \pm \\
16.80\end{array}$ & $\begin{array}{c}61.72^{A} \pm \\
3.59\end{array}$ & $\begin{array}{c}47.06^{B} \pm \\
16.77\end{array}$ & $\begin{array}{c}55.17 \pm \\
15.63\end{array}$ & 5.31 \\
\hline LSD & ns & 10.86 & ns & 13.22 & 5.60 & \\
\hline
\end{tabular}

Means followed by the same small litter at the same column or by the same capital litter at the same row are not significantly different. ANOVA yielded insignificant different between the three parasitoid species $(L S D=1.393, \quad F=1.475)$. 


\section{REFERENCES}

1. Abd El-Hafez, Alia. 1994. Effectiveness of Trichogramma evanescens Westwood and Trichogrammatoidea bactrae Nagraja in parasitizing eggs of Pectinophora gossypiella (Saund.) and Earias insulana (Boisd.). Egypt. J. Biol. Pest. Control 4(1): 113-120.

2. Abd El-Hafez, Alia. 2001. The effect of egg size of the pink bollworm and some lepidopterous insects on the quality attributes of Trichogramma evanescens and Trichogrammatoidea bactrae. Egypt. J. Biol. Pest. Control, 11(1): 1-13.

3. Abd El-Hafez, Alia, A. G. Metwally and M. R. A. Saleh. 1982. Rearing pink bollworm, pectinophora gossypiella (Saund.) on kidney bean diet in Egypt (Lepidoptera: Gelechiidae). Res. Bull., Fac. Agric., Zagazig Univ., April, No.576, 10pp.

4. AN Dahlan Gordon Gordh. 1997. Development of Trichogramma australicum Girault (Hymenoptera: Trichogrammatidae) in fertile and infertile Helicoverpa armigera (Hübner) (Lepidoptera: Noctuidae) eggs. Australian Journal of Entomology Volume 37 Issue 2, Pages 180 - 182.

5. Charnov, E. L., R. L. Los-den Hartogh, W. T. Jones and J. van den Assem. 1981. Sex ratio evolution in a variable environment. Nature99: 27-33.

6. Elsharkawy Manal, A.A. 2002. Mass production and release of Trichogramma spp. to control Pectinophora gossypiella (Saunders) and Earias insulana (Biosd.) Ph.D. (Biological control), Faculty of Agriculture, Moshtohor, Zagazig University.

7. Fahmy, H.S.M., A.H. Zaazou, A.A.M. Kamel and A.H. El Hemaesy. 1973. Effect of temperature and humidity on the immature stages of the greasy cutworm Agrotis ipsilon (Hufn.) (Lepidoptera: Noctudae). Bull. Soc. Ent. Egypt, Econ., 57: 153164.

8. Farid, A., S. Tilal, A. U. Khan, Khattak, S. U. Alamzeb, and Karimullah. 2001. Host age effect on oviposition preference and development of Trichogramma chilonis (Ishii). Pak. J. Biological Science, 4:121- 122.

9. Hutchison, W.D., M. Moratorio and J.M. Martin. 1990. Morphology and Biology of Trichogrammatoidae bactrae (Hymenoptera: Trichogrammatidae), imported from Australia as a parasitoid of pink bollworm (Lepidoptera: Gelechiidae) eggs. Ann. Entomol. Soc. Am. 83: 46-54.

10. King, B. H. 1989. Host-size dependent sex ratios among parasitoid wasps: does host growth matter? Oecologia 78: 420-426.

11. Li, S. Y. and D. E. Henderson. 1993. Response of Trichogramma sp. nr. Sibericum (Hymenoptera: Trichogrammatidae) to age and density of its natural 
hosts, the eggs of Rhopobota naevana (Lepidoptera: Tortricidae). Journal of the Entomological Society of British Columbia 90:18-24.

12. Makee H. 2006. Effect of host egg viability on reproduction and development of Trichogramma cacoeciae and T. principium (Hymenoptera: Trichogrammatidae 10 issues per year Biocontrol Science and Technology, Volume 16, ( 2) 195 204.

13. Miura kazuki. 1998. Effects of host-egg age on the parasitism by Trichogramma chilonis Ishii (Hymenoptera : Trichogrammatidae), an egg parasitoid of the diamondback moth Applied entomology and zoology 33(2), 219-222.

14. Muhammad Zahid, Abid Farid, Abdu Sattar and Inamullah Khan. 2007. Effects of Parasitoid and Host Egg Age On Parasitism by Trichogramma Chilonis (Ishii) J. Sci. Technol. 14(4):381-384.

15. Olson, D. M. 1998. Oviposition and offspring survival within eggs of European corn borere: discrimination of the host embryo by female Trichogramma nubilale. Entomologia Expermintalis et Applicata 87:79-84.

16. PAK, G. A. 2009. Behavioural variations among strains of Trichogramma spp. Journal of Applied EntomologyVolume 101 Issue 1-5, Pages $55-64$.

17. Pak, G. A. and E. R. Oatman. 1982. Biology of Trichogramma brevicapillum. Entomologia Experimentalis et Applicata Volume 32, Number 1

18. Schmidt, J. M. 1994. Host recognition and acceptance by Trichogramma. In: E. Wajnberg \& S. A. Hassan (eds), Biological Control with Egg Parasitoids. CAB International, Wallingford, pp. 165-200.

19. Shoeb, Mona A. 2000. Factor affecting the production of Trichogramma buesi Voegele ( Trichogrammatidae: Hymenoptera) Ph. D. Thesis, Fac. Agrric. Cairo Univ, pp 133.

20. Snedecor, G. W. and W. G. Cochran. 1980. Statistical Methods, $2^{\text {nd }}$ Ed. The lowa State Univeristy Press, Ames, Lowa, pp. 318.

21. Vinson, S. B. 1985 . The behavior of parasitoids. In: G. A. Kerkut \& L. I. Gilbert (eds.), omprehensive Insect Physiology, Biochemistry and Pharmacology. Pergamon Press, Oxford. Vol. 9, pp. 417-469.

22. Vinson, S. B. and G. F. Iwantsch. 1980. Host suitability for insect parasitoids. Annual Review of Entomology 25: 397-419.

23. Waage, J. K. 1982. Sib-mating and sex ratio strategies in scelionid wasps. Ecological Entomology 7: 103-112. 


\section{تأثير عمر البيض وخصوبته على بعض المظاهر البيولوجية لثلاث أنواع من التر/يكوجر/ما}

\section{منال عبد المحسن عبد الغنى الثرقاوى}

$$
\text { معهُ بحوث وقاية النبات - مركز البحوث الزراعية- الدقى - الجبزة }
$$

أجريت تجربتبن معمليتين لتقدير تأثير عمر بيض العائل وخصوبته على بعض المظاهر

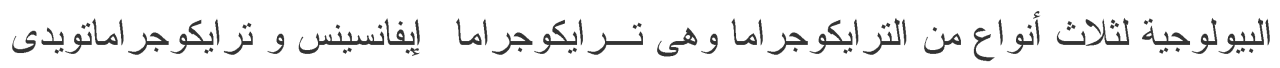

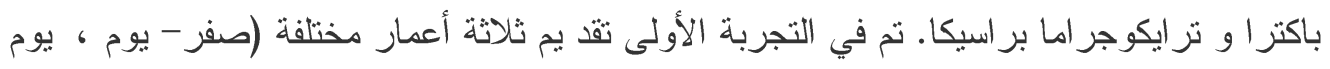

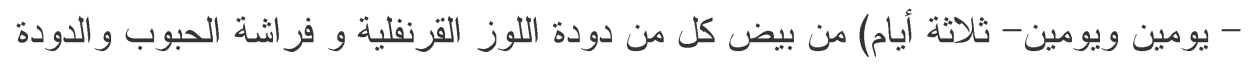

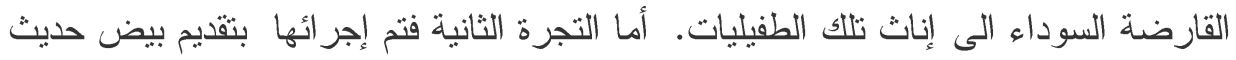

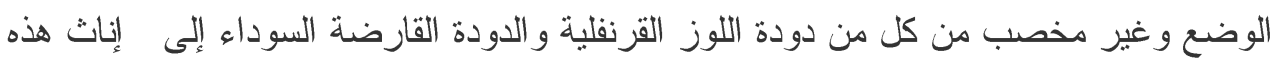
الطفيليات وذلك لدراسة تأثير غياب جنين العائل على نسبة التطفل و نسبة خروج الأطوار الكاملة

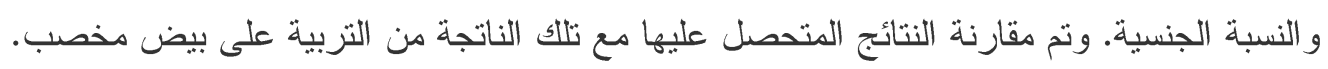

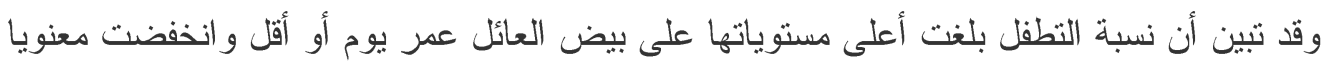

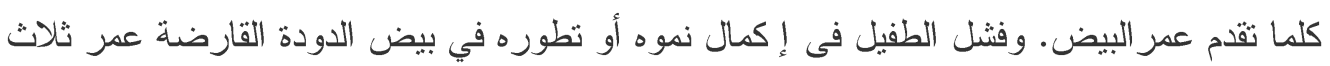

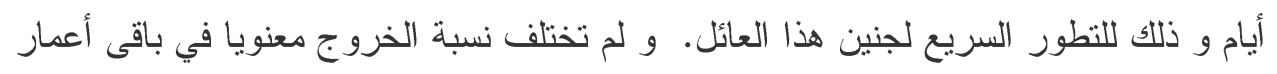

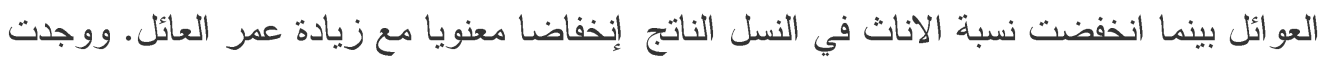
فروق معنوية جدا بين نسبة التطفل في البيض المخصب وغير المخصب. وبصفة عامة كان البيض الغير مخصب غير مناسب لنطور ونمو أنواع الطفيليات الثلاثة. 